\title{
AN EMPIRICAL ANALYSIS ON THE IMPACT OF THE FOREIGN DIRECT INVESTMENTS ON EXPORT PERFORMANCE: TURKEY CASE
}

\author{
Müslüm Basılgan \\ Uludağ University \\ İnegöl Faculty of Business \\ E-mail: muslumbasilgan@uludag.edu.tr \\ ORCID NO: 0000-0001-8307-6315
}

\author{
Ayşe Seha Akman \\ Uludağ University \\ E-mail: 701619013@uludag.edu.tr \\ ORCID NO: 0000-0003-2450-7036
}

\begin{abstract}
While foreign direct investment (FDI) may be a strong source of export incentives in developing countries, its role is still controversial. On the one hand, foreign investment has been suggested to increase exports in developing countries through superior technology and capital, while on the other hand, it is claimed that the role of FDI in encouraging exports depends on the motivations behind this investment. This shows that the nature of the link between FDI and export performance is not clear and should be empirically investigated by country basis. The main purpose of this study is to reveal the effect of foreign direct investments on exports in the case of Turkey.
\end{abstract}

Keywords: FDI Inflows, Export, Cointegration, ARDL, Turkey

JEL Classification: F21, E27, O16

\section{INTRODUCTION}

Economic growth and economic development are core macroeconomic objectives of all countries. An important factor in the achievement of these macroeconomic targets is export performance (Balassa, 1978;1985). However, increasing production and exports level and ensuring development and sustainable growth 


\section{INTERNATIONAL JOURNAL OF ECONOMICS AND FINANCE STUDIES Vol 11, No 2, 2019 ISSN:1309-8055 (Online)}

depends on the level of investment in a country's economy (Solow, 1956; Rostow, 1960; Easterly, 1997; Jagadeesh, 2015). In countries with low incomes and high domestic consumption, sufficient saving shares cannot be allocated from income (Li \& Haiying, 2015), and thus the necessary resources for investment cannot be reached. Therefore, this lack of savings and capital deficit in the country prevents the necessary investments and leads to a vicious cycle in the economy.

Foreign direct investment (FDI) is seen as a way for countries to escape this vicious circle and reach the capital needed for investment (Forgha, 2009). Recent studies have shown that foreign capital investments contribute significantly to economic growth by financing the investments of host countries (Barrell \& Pain, 1997; Borensztein et al., 1998; Choe, 2003; Campos \& Kinoshita, 2002; Almfraj \& Almsafir, 2014; Chakraborty \& Nunnenkamp, 2006; Abor et al., 2008; Mencinger, 2003; Wang \& Wong, 2009; Mehra, 2013).

FDI has benefits not only in terms of capital inflows and economic growth, but also in many other ways. Today, it is accepted that foreign direct investments contribute to technological development through technology transfer in the country they invest (Blomström \& Kokko,1996; Görg \& Strobl, 2005; Lipsey \& Sjöholm, 2005; Buckley \& Frances, 2010), increase the export activities of the country by affecting the diversity and quality of the products that are produced (Pain \& Wakelin, 1998; Kudrle \& Bobrow,1982; Greenaway et al. 2004). Also, it is put forth that foreign direct investments contribute to employment (Craigwell, 2006) and skill development and labor productivity (Buckley et al., 2002; Sun, 2001), encourage existing companies to adopt more efficient methods by increasing competition (Zhang \& Song,2000; Rahmaddi \& Ichihashi, 2013), provide information channels that can be transmitted about foreign market conditions (Buckley et al., 2010; Davaakhuu et al., 2015), and provide access to additional capital for existing domestic companies (Buckley \& Frances, 2010) [by means the possibility of having privileged access to capital].

There is an increasing need for country-wide assesment to demonstrate the impact of foreign direct investments. Turkey's high potential for attracting FDI and importance of export performance in country has increased the importance of putting forth FDI whether it is a tool that supports export performance by using an econometric model. Therefore, the main purpose of this study is to offer suggestions to policymakers by revealing the relationship between FDI inflow and export performance in Turkey. 


\section{INTERNATIONAL JOURNAL OF ECONOMICS AND FINANCE STUDIES Vol 11, No 2, 2019 ISSN:1309-8055 (Online)}

\section{EMPIRICAL LITERATURE}

In empirical studies on the relationship between FDI and exports, causality tests and regression models were used to demonstrate this relationship in different country examples. Jawaid, Raza, Mustafa and Karim (2016) tested the impact of foreign direct investments on export performance in Pakistan by using long-term time series data from 1974 to 2012. As a result of the study, it was seen that FDI had a significant positive effect on real exports in both long and short term. Chou (1988) revealed that the FDI inflows from Japan and the United States into Taiwan have a positive effect on Taiwan's export performance by using the 1983 data of foreign direct companies. In the study, $60 \%$ of the production of American companies and $61 \%$ of the production of Japanese companies were seen to export. Using the monthly data of the 2000 to 2010 period, Göçer and others (2012) tried to put forward the causal relation between foreign direct investments and exports for Turkey by using the Granger causality analysis and ARDL test approach that shows the existence of long and short term relationship between variables. According to the ARDL estimation, results show that a $100 \%$ increment in FDI increased exports by $14 \%$. Zhang (2005), in his empirical study of the impact of FDI inflows on China's export performance, concluded that FDI inflows had a superior effect on industrial level on export performance in China. Leichenko and Erickson (1997) investigated the impact of FDI inflows that come to intermediate goods, industrial machinery and electronics industries on the export performance of the United States. In the study using the least squares method, it is seen that the increment in FDI increased US exports. Pain and Wakelin (1998) who put forward that FDI's impact on host country's exports may vary by industry, country or region, examined the impact of FDI on export performance by taking into account the panel data of 11 OECD countries. The results showed that FDI has a significant positive effect on the export performance on the seven countries that examined in the study, while it reduced export performance in three countries (Japan, Italy and Denmark). Greenawaya and others (2004), in their study by using the 1992-1996 period panel data of incumbent firms in The United Kingdom, revealed that MNC contributes to the country's export by increasing the likelihood of becoming a domestic exporter of foreign companies. Kutan and Vuksic (2007) examined the effects of FDI inflows to 12 Central and Eastern European countries on exports via the period data between 1996-2004. Empirical results from the GLS estimation model show that FDI inflows increase the export potential of host countries. It has been shown that an increase of $100 \%$ FDI stock on the 8 new member countries of the European Union leads to an increase export 


\section{INTERNATIONAL JOURNAL OF ECONOMICS AND FINANCE STUDIES Vol 11, No 2, 2019 ISSN:1309-8055 (Online)}

performance of $16 \%$ in the short term and $42 \%$ in the long-term. Alic1 and Ucal (2003), by using quarterly data from 1987 to 2002, have analyzed the causal relationship among FDI, exports and economic growth in Turkey. In the study, there was no growth in exports due to direct investment in Turkey. Clus-Rossouw, Viviers and Loots (2015) conducted a study to demonstrate whether FDI inflows from BRIC (Brazil, Russia, India, China and South Africa) countries to SADC (Southern African Development Community) countries affect export performance. In the study, which used FDI data between 2003 and 2010, a significant relationship (96\%) was found between FDI and SADC countries' exports to the world. Zhang and Song (2000) examined the relationship between export performance among China's provinces and FDI flows by using provincial-level panel data during the period 1986-1997. The findings showed that increasing FDI levels have a positive effect on export performance in provincial production. The study found that a $1 \%$ increase in FDI in the previous year led to a $0.29 \%$ increase in exports in the following year (See also other country examples about impacts of FDI on exports. Gu and Awokuse for China (2008), Kiran (2010), Klasra (2011) and Bozdağlığlu ve Özpınar (2011) for Turkey, Rahmaddi and Ichihashi for Indonesia (2013), Abor and others (2008) for Ghana, Lin (1995) for ASEAN (Indonesia, Malaysia, Philippines and Thailand), Hejazi and Safarian (2001) for the USA, Nguyen \& Yuqing (2008) for Vietnam, Kneller and Pisu (2007) for England, Khan, Wang, Hassan (2018) for Pakistan, Adhikary (2012) for Bangladesh, Kueh and others (2007) for Asian countries (Indonesia, Malaysia, Philippines, Singapore and Thailand)).

In summary, although the empirical studies given above in both developing and developed countries show that there is a positive relationship between FDI and exports mainly, but the degree of influence is varies from country to country. This situation shows that it varies according to the economic situation or specific characteristics of the countries.

\section{RESEARCH METHOD AND EMPIRICAL ANALYSIS}

\subsection{Method of Research}

This study examines the impact of FDI inflows on Turkey's export performance by using the ARDL bounds testing approach and cointegration analysis for 2005 / 1-2018 / 7 period. A research model has been defined which aims to examine the effects of FDI, industrial production index (IPI), domestic producer price index 


\section{INTERNATIONAL JOURNAL OF ECONOMICS AND FINANCE STUDIES Vol 11, No 2, 2019 ISSN:1309-8055 (Online)}

(PPI), PPI-based real effective exchange rate (RER) and domestic commercial credits interest rates (CCIR) on export (EX) figures. The monthly export amount, monthly FDI amount, PPI based real effective exchange rate and domestic commercial credit interest rates were obtained from the Central Bank of Turkey. Domestic producer price index and monthly industrial production index data were obtained from the Turkish Statistical Institute. The econometric representation of the economic model adopted in the research is as in Equation 1.

$$
\mathrm{EX}_{\mathrm{t}}=\beta_{0}+\beta_{1}\left(\mathrm{FDI}_{\mathrm{t}}\right)+\beta_{2}\left(\mathrm{IPI}_{\mathrm{t}}\right)+\beta_{3}\left(\mathrm{PPI}_{\mathrm{t}}\right)+\beta_{4}\left(\mathrm{RER}_{\mathrm{t}}\right)+\beta_{5}\left(\mathrm{CCIR}_{\mathrm{t}}\right)+\varepsilon_{\mathrm{t}}
$$

In this study, the export variable constitutes the dependent variable of the research. In this respect, the effects of selected independent variables on export figures will be examined.

In time series, most of the econometric analysis methods based on the assumption that the variables used in the model are stationary at the same level. The assumption of stationarity requires that non-stationary series at the level are taken into the econometric model by taking first difference. Therefore, firstly, the relations between the variables will be revealed by ARDL boundary test approach and cointegration analysis.

Since the seasonality analysis and trend analysis of the variables in the model are the priori knowledge that should be known in the time series analysis, these analyses have been done first.

According to the results of the regression, it was determined that there was a seasonality in the series. Variables are seasonally adjusted by X-12 ARIMA method.

\subsection{Unit Root Analysis}

In this study, the stationarity of the series was examined by the ADF (Augmented Dickey-Fuller) test. Natural logarithmic transformations of the series were performed before the stationarity test was started. Since it is not recommended to apply the logarithmic transformations to variables which are participating the analysis in the form of index, rate and percentage, the economic model was revised as in Equation 2 by applying the logarithmic transformation of the export and foreign direct investment variables. 


\section{INTERNATIONAL JOURNAL OF ECONOMICS AND FINANCE STUDIES Vol 11, No 2, 2019 ISSN:1309-8055 (Online)}

$\log \left(\mathrm{EX}_{\mathrm{t}}\right)=\beta_{0}+\beta_{1}\left(\log \left(\left(\mathrm{FDI}_{-} \mathrm{sa}_{\mathrm{t}}\right)^{*}\right)+\beta_{2}\left(\mathrm{IPI}_{\mathrm{t}}\right)+\beta_{3}\left(\mathrm{PPI}_{\mathrm{t}}\right)+\beta_{4}\left(\mathrm{RER}_{\mathrm{t}}\right)+\beta_{5}\left(\mathrm{CCIR}_{\mathrm{t}}\right)+\varepsilon_{\mathrm{t}}\right.$ (2)

ADF unit root test statistics specifications of variables which are intercept, trendintercept and neither an intercept nor a time trend are shown in Table 1.

Table 1: ADF Unit Root Test Statistics

\begin{tabular}{|c|c|c|c|c|c|c|}
\hline \multirow{2}{*}{ Variable } & \multicolumn{2}{|l|}{ None } & \multicolumn{2}{|l|}{ Intercept } & \multicolumn{2}{|c|}{ Trend-Intercept } \\
\hline & $\mathbf{T}$ & $\mathbf{P}$ & $\mathbf{t}$ & p & $\mathbf{t}$ & $\mathbf{P}$ \\
\hline $\log (\mathrm{EX})(2)$ & 1.153 & 0.935 & -2.084 & 0.251 & -2.727 & 0.227 \\
\hline$\Delta \log (\mathrm{EX})(1)$ & $-14.140 * * *$ & 0.000 & $-14.211 * * *$ & 0.000 & $-14.204 * * *$ & 0.000 \\
\hline $\log (\mathrm{FDI})(4)$ & 0.318 & 0.776 & -4.125 & 0.001 & -4.0457 & $0.009 *$ \\
\hline$\Delta \log (\mathrm{FDI})(3)$ & $-11.818 * * *$ & 0.000 & $-11.801 * * *$ & 0.000 & $-11.844 * * *$ & 0.000 \\
\hline RER (0) & -8.861 & 0.341 & -0.699 & 0.842 & -3.290 & 0.071 \\
\hline$\triangle \mathrm{RER}(0)$ & $-10.997 * * *$ & 0.000 & $-11.015 * * *$ & 0.000 & $-11.047 * * *$ & 0.000 \\
\hline IPI (1) & 3.574 & 0.999 & 0.569 & 0.988 & -1.613 & 0.783 \\
\hline$\Delta \mathrm{IPI}(0)$ & $-16.235^{* * *}$ & 0.000 & $-17.171 * * *$ & 0.000 & $-17.212 * * *$ & 0.000 \\
\hline CCIR (1) & -0.339 & 0.561 & -1.858 & 0.351 & -1.277 & 0.889 \\
\hline$\Delta \mathrm{CCIR}(0)$ & $-9.306 * * *$ & 0.000 & $-9.275 * * *$ & 0.000 & $-9.526 * * *$ & 0.000 \\
\hline PPI (1) & 4.160 & 1.000 & 2.848 & 1.000 & 1.888 & 1.000 \\
\hline$\Delta \mathrm{PPI}(0)$ & $-4.894 * * *$ & 0.000 & $-6.077 * * *$ & 0.000 & $-6.658 * * *$ & 0.000 \\
\hline
\end{tabular}

*** represents presence of unit the root at the significance level of $1 \% . \Delta(\mathrm{X})$ represents the first difference of the variable X. For optimal lenght of lag in ADF regression, Schwarz's information criterion was used.

It is known that many time series analyzes are based on the assumption that the variables are stationary at same level. And also it is known that the process of taking difference causes loss of actual relationship with loss of variability. ARDL model assume that the relationship between variables can be explored regardless of how stationary level they are, unless second different level (I(2)). (Pesaran et al., 2001). When the ADF unit root test was evaluated in general, all series are not stationary at level $(\mathrm{I}(0))$ by all the specifications calculated, but they are stationary at the first difference (I(1)). The results of the unit root analysis show that the long and short term relationships between the variables can be examined by ARDL boundary test.

\footnotetext{
${ }^{*}$ fdi_sa $=$ represents the seasonally adjusted fdi variable.
} 


\section{INTERNATIONAL JOURNAL OF ECONOMICS AND FINANCE STUDIES \\ Vol 11, No 2, 2019 ISSN:1309-8055 (Online)}

\subsection{Estimation of the Model by ARDL Boundary Test Method}

Cointegration analysis constitutes the first stage of the ARDL boundary test approach. In the second stage, short and long term coefficients of the series are calculated.

The null hypothesis for the cointegration relationship between variables; $\mathrm{H} 0: \beta 1=$ $\beta 2=\beta 3=\beta 4=\beta 5=0$. If the calculated test statistic is greater than the upper bound value, the null hypothesis stating that there is no cointegration relationship is rejected and it is decided that there is cointegration (Pesaran et al., 2001).

In the boundary test approach, Equation 3 was estimated in order to test the longterm relationship.

$\Delta \log \left(E X_{t}\right)=\beta_{0}+\beta_{1} \log \left(\mathrm{EX}_{\mathrm{t}-1}\right)+\beta_{2} \log ($ FDI_sa $)+\beta_{3} \mathrm{RER}_{\mathrm{t}}+\beta_{4}+\mathrm{IPI}_{\mathrm{t}}+\beta_{5} \mathrm{CCIR}_{\mathrm{t}}+$ $\beta_{6} \mathrm{PPI}_{\mathrm{t}}+\sum_{i=1}^{p} \delta_{i} \Delta \log \left(E X_{t-1}\right)+\sum_{i=0}^{q 1} \lambda_{i 1} \Delta \log \left(F D I_{-} s a_{t-i 1}\right)$

$+\sum_{i=0}^{q 2} \lambda_{i 2} \Delta R E R_{t-i 2}+\sum_{i=0}^{q 3} \lambda_{i 3} \Delta I P I_{t-i 3}+\sum_{i=0}^{q 4} \lambda_{i 4} \Delta C C I R_{t-i 4}+$ $\sum_{i=0}^{q 5} \lambda_{i 5} \Delta P P I_{t-i 5}+\varepsilon_{\mathrm{t}}$

In the equation, $\mathrm{p}$ express the optimal lag in the dependent variable; $\mathrm{q} 1, \mathrm{q} 2, \mathrm{q} 3$, $\mathrm{q} 4$, q5 express optimal lag in the independent variables; $\beta 0, \beta 1, \beta 2, \beta 3, \beta 4, \beta 5$, $\lambda \mathrm{i} 1, \lambda \mathrm{i} 2, \lambda \mathrm{i} 3, \lambda \mathrm{i} 4, \lambda \mathrm{i} 5$ and $\delta$ i express coefficients; $\Delta$ express the difference of the variable.

For boundary test analysis, the ARDL (p, q1, q2, q3, q4, q5) model shown in Equation 4 was estimated:

$\log \left(\mathrm{EX}_{\mathrm{t}}\right)=\beta_{0}+\sum_{i=1}^{p} \delta_{i} \log \left(E X_{t-i}\right)+\sum_{i=0}^{q 1} \lambda_{i 1} \log \left(F D I_{-} s a_{t-i 1}\right)$ $+\sum_{i=0}^{q 2} \lambda_{i 2} R E R_{t-i 2}+\sum_{i=0}^{q 3} \lambda_{i 3} I P I_{t-i 3}+\sum_{i=0}^{q 4} \lambda_{i 4} C_{C C I R_{t-i 4}}+\sum_{i=0}^{q 5} \lambda_{i 5} P P I_{t-i 5}+\mu_{\mathrm{t}}$ (4)

For the ARDL (p, q1, q2, q3, q4, q5) model, long-term coefficients for each independent variable are estimated as in Equation 5.

$\frac{\lambda_{1}+\lambda_{2}+\lambda_{3} \cdots \cdot \lambda_{q}}{\delta_{1}+\delta_{2}+\delta_{3}+\cdots \cdot \delta_{p}}$ 


\section{INTERNATIONAL JOURNAL OF ECONOMICS AND FINANCE STUDIES Vol 11, No 2, 2019 ISSN:1309-8055 (Online)}

After estimating long-term coefficients, the short-term coefficients are obtained by using the error correction model in Equation 6. EC in the equation refers to the error correction term. In order to test the existence of causality relationship from independent variables to the dependent variable, it is necessary to look at the significance of the error correction term.

$$
\begin{aligned}
& \Delta \mathrm{Y}_{\mathrm{t}}=\beta_{0}+\beta_{1} \mathrm{EC}_{\mathrm{t}-1}+\sum_{i=1}^{p} \delta_{i} \Delta \log \left(E X_{t-i}\right)+\sum_{i=0}^{q 1} \lambda_{i 1} \Delta \log \left(F D I_{-} s a_{t-i 1}\right) \\
& +\sum_{i=0}^{q 2} \lambda_{i 2} \Delta R E R_{t-i 2}+\sum_{i=0}^{q 3} \lambda_{i 3} \Delta I P I_{t-i 3}+\sum_{i=0}^{q 4} \lambda_{i 4} \Delta C C I R_{t-i 4}+ \\
& \sum_{i=0}^{q 5} \lambda_{i 5} \Delta P P I_{t-i 5}+\mu_{\mathrm{t}}
\end{aligned}
$$

\subsection{Findings}

For the estimation of the ARDL (p, q1, q2, q3, q4, q5) model, the optimal lag lengths were determined. Akaike information criterion has been taken into consideration for determination of lag lengths.

Since the Akaike Information Criterion is a statistic based on the error sum of residual squares, the smaller AIC indicates a better model. The lowest Akaike value was defined as $\operatorname{ARDL}(12,12,12,8,12,9)$. In this case, the model is defined as ARDL $(12,12,12,8,12,9)$. Optimal lag lengths are Log (ex) 12, log (fd1_sa) 12, rer 12, ipi 8, ccir 12 and pp1 9. After determining the optimal lag lengths, the model in Equation 3 is estimated. The obtained results are shown in Table 2. 


\section{INTERNATIONAL JOURNAL OF ECONOMICS AND FINANCE STUDIES Vol 11, No 2, 2019 ISSN:1309-8055 (Online)}

Table 2: ARDL $(12,12,12,8,12,9)$ Model Estimation

\begin{tabular}{lllll}
\hline Variables & Coefficient & Standard Error & $\mathrm{t}$ & $\mathrm{P}$ \\
\hline $\mathrm{C}$ & 2.14834 & 0.80103 & 2.68198 & $0.00890^{* * *}$ \\
$\mathrm{Log}(\mathrm{FDI})$ & 0.09572 & 0.05282 & 1.81230 & $0.07370^{*}$ \\
$\mathrm{RER}(-1)$ & -0.00375 & 0.00319 & -1.17553 & 0.24330 \\
$\mathrm{IPI}(-1)$ & 0.00610 & 0.00273 & 2.23766 & $0.02800^{* *}$ \\
$\mathrm{CCIR}(-1)$ & -0.01282 & 0.00470 & -2.73073 & $0.00780^{* * *}$ \\
$\mathrm{PPI}(-1)$ & -0.00282 & 0.00105 & -2.68444 & $0.00880^{* * *}$ \\
\hline $\mathrm{F}=21.4885, \mathrm{~F}(\mathrm{p})=0.0000^{* * *}$ & & & \\
Adjusted R-squared=0.9053 & & & & \\
\hline Diagnostic Tests & & 0.7198 & & \\
\hline Breusch-Pagan-Godfrey & $\mathrm{F}$ & 0.9196 & & \\
Heteroskedasticity Test & $\mathrm{P}$ & 1.1896 & & \\
\hline Breusch-Pagan-Godfrey & $\mathrm{F}$ & 0.3062 & & \\
LM Test & $\mathrm{P}$ & $5.92 \mathrm{e}-15=0$ & & \\
\hline & Mean & 1.4672 & & \\
Error Terms & Jarque-Berra F & 0.4801 & & \\
& $\mathrm{~J}-\mathrm{B}(\mathrm{p})$ &
\end{tabular}

$*, * *$ and $* * *$ represent respectively $\% 1, \% 5$ and $\% 10$ the level of significance.

When the table is examined, it is seen that the effect of lagged values of all variables is statistically significant on Log (ex) except rer (-1) variable. When the $p$ value of the $f$ statistics of the model is examined, it is seen that the model is significant as a whole at $1 \%$ significance level. $\mathrm{H} 0: \beta 1=\beta 2=\beta 3=\beta 4=\beta 5=0$ hypothesis has rejected and it is accepted that there is cointegration between the series $(\mathrm{p}<0.01)$.

Cusum test and Cusum Q tests were used for stability tests of model. These tests showed that there was no value that go out of the 5\% significance level band and show that the predicted regression equation was stable and that there were no structural breaks during the period under consideration. After examining the error correction model, the long and short term coefficients of the model will be interpreted.

ARDL error correction model estimation statistics and border test statistics are presented in Table 3. Table 3 of ARDL error correction model estimation statistics contains statistics about cointegration. 


\section{INTERNATIONAL JOURNAL OF ECONOMICS AND FINANCE STUDIES}

Vol 11, No 2, 2019 ISSN:1309-8055 (Online)

Table 3: ARDL Error Correction Model and Boundary Test Statistics

\begin{tabular}{lllll}
\hline Variable & Coefficient & Standard Error & T & p \\
\hline ECM & -0.24112 & 0.04018 & -6.00071 & $0.00000^{* * *}$ \\
\hline Bound Testing & & & & \\
\hline & $\mathrm{f}$ & Significance & Lower & Upper \\
\hline F Test & $4.78518^{* * *}$ & $10 \%$ & 2.08 & 3 \\
& & $5 \%$ & 2.39 & 3.38 \\
& & $1 \%$ & 3.06 & 4.15
\end{tabular}

When the error correction term (ECM) is examined in the table, it is seen that it is significant at $1 \%$ significance level and it has a negative value between 0 and $1(\mathrm{p}$ $<0.01$ ). Boundary test statistics were found to be significant at $1 \%, 5 \%$ and $10 \%$ significance levels when it compared with lower and upper values $(\mathrm{p}<0.01)$. This shows that there is a long-term cointegration relationship between the variables. The estimation statistics for the long-term cointegration relationship are presented in Table 4.

Tablo 4: ARDL Long Term Balance Estimation Statistics

\begin{tabular}{lllll}
\hline Variable & Coefficient & Standard Error & $\mathrm{T}$ & $\mathrm{p}$ \\
\hline $\log (\mathrm{FDI})$ & 0.39697 & 0.16318 & 2.43277 & $0.01720^{* *}$ \\
\hline RER & -0.01556 & 0.01373 & -1.13317 & 0.26050 \\
\hline IPI & 0.02529 & 0.01485 & 1.70283 & $0.09250^{*}$ \\
\hline CCIR & -0.05319 & 0.01401 & -3.79723 & $0.00030^{* * *}$ \\
\hline PPI & -0.01168 & 0.00684 & -1.70729 & $0.09160^{*}$ \\
\hline C & 8.90982 & 1.93657 & 4.60083 & $0.00000^{* * *}$
\end{tabular}

According to Table 4, the long-term estimation results of the model are as follows. The effect of the FDI variable on export figures was significant and positive at $5 \%$ significance level $(\beta=0.396, \mathrm{p}<0.05)$. More specifically, a $1 \%$ increase in foreign direct investments in the long term also increases the long-term export figures by $0.39 \%$. The effect of real exchange rate on export figures was not statistically significant $(\beta=-0.015, \mathrm{p}>0.10)$. The effect of the industrial production index on exports was significant and positive at $10 \%$ significance level $(\beta=0.025, p<0.10)$, while the effect of commercial credits rates on exports was significant and negative at $1 \%$ significance level $(\beta=-0.053, \mathrm{p}<0.01)$. The effect 


\section{INTERNATIONAL JOURNAL OF ECONOMICS AND FINANCE STUDIES \\ Vol 11, No 2, 2019 ISSN:1309-8055 (Online)}

of the producer price index on exports was significant and negative at the $10 \%$ significance level $(\beta=-0.011, \mathrm{p}<0.10)$.

Table 5: ARDL Short Term Balance Estimation Statistics

\begin{tabular}{lllll} 
Variable & Coefficient & Standard Error & $\mathrm{t}$ & $\mathrm{p}$ \\
\hline LOG_FDI_SA(-1) & 0.09572 & 0.05282 & 1.81230 & $0.07370^{*}$ \\
\hline RER(-1) & -0.00375 & 0.00319 & -1.17553 & 0.24330 \\
\hline IPI(-1) & 0.00610 & 0.00273 & 2.23766 & $0.02800^{* *}$ \\
\hline CCIR(-1) & -0.01282 & 0.00470 & -2.73073 & $0.00780^{* * *}$ \\
\hline PPI(-1) & -0.00282 & 0.00105 & -2.68444 & $0.00880^{* * *}$ \\
\hline C & 2.14834 & 0.80103 & 2.68198 & $0.00890^{* * *}$
\end{tabular}

According to Table 5, the short-term estimation results of the model are as follows. It is concluded that the effect of a lagged value of foreign direct investments on the period value of exports is significant and positive at $10 \%$ significance level $(\beta=0.09, p<0.10)$. More specifically, a $1 \%$ increase in FDI led to an increase of approximately $0.09 \%$ in exports. The effect of a lagged value of the real exchange rate on the period value of export is not statistically significant $(\beta=-0.003, p>0.10)$. The effect of a lagged value of the industrial production index on the period value of exports is significant and positive at $5 \%$ significance level $(\beta=0.006, p<0.10)$. The effect of a lagged value of commercial credits interest rates on the period value of exports was significant and negative at $1 \%$ significance level $(\beta=-0.012, p<0.01)$. The effect of a lagged value of the producer price index on the period value of exports was found to be significant and negative at $1 \%$ significance level $(\beta=-0.002, p<0.01)$.

\section{GENERAL EVALUATION AND CONCLUSION}

In this study, the effect on the export performance of Turkey's FDI inflows were analyzed using an econometric model. According to the model created in the study, the effect of foreign direct investments on exports was statistically significant and positive. According to the results of the model, a $100 \%$ increment in foreign direct investments increases export figures by $39 \%$ in the long run. This result is suitable for the general trend in the literature. The effect of commercial credit interest rates on export figures was found to be statistically significant and negative. Producer price index has a decreasing effect on export figures. In the 


\section{INTERNATIONAL JOURNAL OF ECONOMICS AND FINANCE STUDIES Vol 11, No 2, 2019 ISSN:1309-8055 (Online)}

Turkey case, there was no connection between the real exchange rate and exports. Although the studies investigating the relationship between real effective exchange rate and export performance in literature give complicated results (Malhotra, Kumari, 2015), according to traditional theory of international economics, a higher exchange rate makes the product of Turkey cheaper, and this leads to an increase in exports. An explanation of the different results in our model is the necessity of imports of inputs and components that are used in the production of goods that form a large part of exports of Turkey. The production of these goods results in cost pressure that will lead to a reduction in exports. The effect of the industrial production index, which represents the increase in goods produced in the country compared to the previous period, was positive in line with the general trend.

These results show us that FDI inflows play a role in increasing exports in Turkey. The realization of this role is possible through supportive policies. In this regard, more encouraging foreign investment policies can be applied by determining export-oriented sectors in Turkey.

\section{REFERENCES}

Abor, J., Adjasi, C., \& Hayford, M.-C. (2008). How Does Foreign Direct Investment Affect the Export Decisions of Firms in Ghana?. African Development Review, 20(3), 446-465.

Adhikary, B. K. (2012). Impact of Foreign Direct Investment, Trade Openness, Domestic Demand, and Exchange Rate on the Export Performance of Bangladesh: A VEC Approach. Hindawi Publishing Corporation Economics Research International Volume, 4(5), 216-226.

Alıc1, A. A., \& Ucal, M. (2003). Foreign Direct Investment, Exports and Output Growth of Turkey: Causality Analysis. Proceeding of the 5th Annual Conference on European Trade Study Group, Sept. 11-13 (s. 1-19). Madrid: Universidad Carlos III de Madrid.

Almfraji, M. A., \& Almsafir, M. (2014). Foreign Direct Investment and Economic Growth Literature Review from 1994 to 2012. Procedia - Social and Behavioral Sciences, $206-213$. 


\section{INTERNATIONAL JOURNAL OF ECONOMICS AND FINANCE STUDIES Vol 11, No 2, 2019 ISSN:1309-8055 (Online)}

Balassa, B. (1985). Exports, Policy Choices, And Economic Growth in Developing Countries After The 1973 Oil Shock. Journal of Development Economics, 18(1), 23-35.

Balassa, B. (1978). Exports and economic growth: Further evidence. Journal of Development Economics, 5(2), 181-189.

Barrell, R., \& Pain, N. (1997). Foreign Direct Investment, Technological Change, and Economic Growth Within Europe. The Economic Journal, 445(107), 1770-1786.

Blomström, M., \& Kokko, A. (1996). Multinational Corporations and Spillovers. London: Centre for Economic Policy Research.

Borensztein, E., Gregorio, J., \& Lee, J.-W. (1998). 'How Does Foreign Direct Investment Affect Economic Growth?'. Journal of International Economics, s 115-135.

Bozdağlığlu, E. Y., \& Özpınar, Ö. (2011). Türkiye'ye Gelen Doğrudan Yabancı Yatırımların Türkiye'nin İhracat Performansına Etkilerinin VAR Yöntemi ile Tahmini. Dokuz Eylül Üniversitesi Sosyal Bilimler Enstitüsü Dergisi, 13(1), 39-63.

Buckley, P. (2010). Stephen Hymer: Three Phases, One Approach?. P. J. Buckley içinde, Foreign Direct Investment, China And The World Economy (s. 15-24). London.

Buckley, P., \& Frances, R. (2010). Foreign Direct Investment in Ireland:Policy Implications for Emerging Economies. P. J. Buckley içinde, Foreign Direct Investment, China and the World Economy (Cilt 29, s. 365-385). London: Palgrave Macmillan.

Buckley, P., Clegg, J., Wang, C., \& Cross, A. (2002). FDI, Regional Differences and Economic Growth: Panel Data Evidence from China. Transnational Corporations, 11(1), 1-28.

Campos, N. F., \& Kinoshita, Y. (2002). Foreign Direct Investment as Technology Transferred: Some Panel Evidence from the Transition Economies. William Davidson Working Paper Number 438.

Chakraborty, C., \& Nunnenkamp, P. (2006). Economic Reforms, Foreign Direct Investment and its Economic Effects in India. Kiel Working Paper No. 1272. 


\section{INTERNATIONAL JOURNAL OF ECONOMICS AND FINANCE STUDIES Vol 11, No 2, 2019 ISSN:1309-8055 (Online)}

Choe, J. I. (2003). 'Do Foreign Direct Investment and Gross Domestic Investment Promote Economic Growth?. Review of Development Economics, 7(1), 44-57.

Chou, T.- C. (1988). American and Japanese direct foreign investment in Taiwan: a comparative study. Hitotsubashi Journal of Economics, 29, 165-179.

Clus-Rossouw, D. 1., Viviers, W., \& Loots, E. (2015). Is there a link between BRIC foreign direct investment and SADC export performance? Development Southern Africa, 32(6), 658-674.

Craigwell, R. (2006). Foreign Direct Investment and Employment in the English and Dutch-Speaking Caribbean. Working Papers. Tripartite Caribbean Employment Forum.

Davaakhuu, O., Sharma, K., \& Oczkowski, E. (2015). Has foreign investment played a role in Mongolia's export success?. Post-Communist Economies, 27(2), 256-267.

Easterly, W. (1997). The Ghost of Financing Gap: How The HarrodDomar Growth Model Stil Haunts Development Economics. World Bank.

Forgha, N. G. (2009). Foreign Direct Investment and Economic Performance in Cameroon. International Review of Business Research, 5 (1), January, 55-69.

Göçer, İ., Bulut, S., \& Dam, M. (2012). Doğrudan Yabancı Yatırımların Türkiye'nin İhracat Performansına Etkileri: Ekonometrik Bir Analiz. Business and Economics Research Journal.

Görg, H., \& Strobl, E. (2005). Foreign Direct Investment and Local Economic Development: Beyond Productivity Spillovers. Editörler T. Moran, E. Graham, \& M. Blomström, Does Foreign Direct Investment Promote Development? (Cilt 107, s. 137-157). Washington DC,Institute for International Economics.

Greenaway, D., Sousab, N., \& Wakelina, K. (2004). Do Domestic Firms Learn To Export From Multinationals?. European Journal of Political Economy, 20, 1027-1043.

Gu, W., \& Awokuse, T. (2008). The Contribution of Foreign Direct Investment to China's Export Performance: Evidence from Disaggregated Sectors. The American Agricultural Economics Association Annual Meeting. Orlando. 


\section{INTERNATIONAL JOURNAL OF ECONOMICS AND FINANCE STUDIES Vol 11, No 2, 2019 ISSN:1309-8055 (Online)}

Hejazi, W., \& Safarian, A. E. (2001). The Complementarity Between U.S. Foreign Direct Investment Stock and Trade. Atlantic Economic Journal, 4(29), 420-437.

Jagadeesh, D. (2015). The Impact of Savings in Economic Growth: An Empirical Study Based on Botswana. International Journal of Research in Business Studies and Management, 2(9), 10-21.

Jawaid, S., Raza, S., Mustafa, K., \& Karim, M. (2016). Does Inward Foreign Direct Investment Lead Export Performance in Pakistan ?. Global Business Review, 17(6), 1296-1313.

Khan, Y., Wang, M., \& Hassan, T. (2018). Foreign Direct Investment and Import-Export: The case of Pakistan. Research Journal of Economics.

Kiran, B. (2010). Causal Links Between Foreign Direct Investment and Trade in Turkey. International Journal of Economics and Finance, 3(2), 150-158.

Klasra, M. A. (2011). Foreign Direct İnvestment, Trade Openness And Economic Growth İn Pakistan and Turkey: An İnvestigation Using Bounds Test. Quality \& Quantity, 223-231.

Kneller, R., \& Pisu, M. (2007). Industrial Linkages and Export Spillovers from FDI. The World Economy, 30(1), 105-134.

Kudrle, R., \& Bobrow, D. (1982). U.S. Policy toward Foreign Direct Investment. World Politics, 34, 353-79.

Kueh, J. S.-H., Puah, C.-H., Lau , E., \& Mansor, S. (2007). FDI-trade Nexus: Empirical Analysis on ASEAN-5. Munich Personal RePEc Archive.

Kutan, A., \& Vuksic, G. (2007). Foreign Direct Investment and Export Performance. Association for Comparative Economic Studies.

Leichenko, R. M., \& Erickson, R. A. (1997). Foreign Direct Investment and State Export Performance. Journal of Regional Science(37), 307-329.

Li, P., \& Haiying, M. (2015). An Empirical Analysis of Economic Development in Northwest China: Based on the Vicious Circle of Poverty Demands Theory. International Journal of Business Administration, 6(4), 57-63.

Lin, A. (1995). Trade Effects of Foreign Direct Investment: Evidence For Taiwan with Four ASEAN Countries. Weltwirtschaftliches Archiv (131), 737-747.

Lipsey , R., \& Sjöholm, F. (2005). The Impact of Inward FDI on Host Countries: Why Such Different Answers?. Editörler R. E. Lipsey, F. Sjöholm, T. 


\section{INTERNATIONAL JOURNAL OF ECONOMICS AND FINANCE STUDIES Vol 11, No 2, 2019 ISSN:1309-8055 (Online)}

Moran, E. Graham, \& M. Blomström, Does Foreign Direct Investment Promote Development? (s. 23-43). Washington DC., Institute for International Economics.

Malhotra, N., \& Kumari, D. (2015). Determinants of Exports in Major Asian Economies. Journal of International Economics, 6(2), 94-110.

Mehra, N. (2013). Impact of Foreign Direct Investment on Employment and Gross Domestic Product in India. International Journal Economic Res., 29 38 .

Mencinger, J. (2003). Does Foreign Direct Investment Always Enhance Economic Growth?. KYKLOS, 56, 491-508.

Nguyen, T., \& Yuqing, X. (2008). Foreign Direct Investment and Exports: the Experiences of Vietnam. GSIR Working Papers Economic Development \& Policy Series.

Pain, N., \& Wakelin, K. (1998). Export Performance and The Role of Foreign Direct Investment. The Manchester School Supplement, 62-88.

Pesaran, M. H. \& Shin, Y., \& Smith, R.J. (2001). Bounds Testing Approaches to the Analysis of Level Relationships. Journal of Applied Econometrics, 16, 289-326.

Rahmaddi, R., \& Ichihashi, M. (2013). The Role of Foreign Direct Investment in Indonesia's Manufacturing Exports. Bulletin of Indonesian Economic Studies, 49(3), 329-54.

Rostow, W. W. (1960). The Stages of Economis Growth a Non-Communist Manifesto. Cambridge : Cambridge University Press.

Solow, T. (1956). A Contribution to the Theory of Economic Growth. Quarterly Journal of Economics, 65-94.

Sun, H. (2001). Foreign Direct Investment and Regional Export Performance in China. Journal o Regional Science, 41(2), 317-336.

Wang, M., \& Wong, M. (2009). What Drives Economic Growth? The Case of Cross Border M\&A and Greenfield FDI Activities. Kyklos, 62(2), 316330.

Zhang, K. H. (2005). How Does FDI Affect a Host Country's Export Performance? The Case of China. International conference of WTO, China, The Asian Economics, III Xi'an, China, 25-26, June. 
INTERNATIONAL JOURNAL OF ECONOMICS AND FINANCE STUDIES

Vol 11, No 2, 2019 ISSN:1309-8055 (Online)

Zhang, K. H., \& Song, S. (2000). Promoting Exports The Role of Inward FDI in China. China Economic Review, 11(4), 385-396. 